\title{
NECROLÓGIO
}

\section{ASCÂNIO DE FARIA (1903-1987)}

A criação da truta arco-íris, Salmo irideus, hoje é uma realidade no Brasil, principalmente nas regiōes montanhosas de São Paulo e Minas Gerais. Entretanto, pouca gente sabe quem foi o responsável pela introdução dessa espécie no Brasil: o veterinário Ascânio de Faria, como veremos mais adiante.

Ascânio de Faria era filho de Paulo e Rita Torres de Faria, tendo nascido em Itaocara, RJ, no dia 25 de julho de 1903 e falecido na cidade do Rio de Janeiro em 21 de março de 1987.

A sua formatura em medicina veterinária deu-se no dia 3 de janeiro de 1926, pela Escola Superior de Agricultura e Medicina Veterinária do Rio de Janeiro, que na época funcionava na Praia Vermelha. Ele foi o primeiro aluno de sua turma e recebeu uma medalha de ouro.

Seu primeiro emprego foi como veterinário no Serviço de Indústria Pastoril do Ministério da Agricultura, Indústria e Comércio, chefiando o posto de assistência em Cruz Alta, RS. De 1927 a 1929 foi inspetor veterinário, encarregado de examinar o leite e seus derivados no Paraná e Santa Catarina. Em 1931 era professor da Escola Superior de Agricultura e Medicina Veterinária, quando começou a pesquisar doenças de cães e gatos, em colaboração com Américo Braga. Com esse colega publicou dados sobre neuro-histopatologia da cinomose (1934), paralisia bulbar infectuosa (1934) e processos patológicos da membrana nictitante do cão e do gato (1935). Em 1932 fez parte de uma comissão que estudou a raiva no alto Rio Branco, AM, e esteve na Guiana Inglesa.

Em março de 1933 foi nomeado hidrobiologista da Inspetoria de Caça e Pesca da Diretoria Geral de Indústria Animal, do Ministério da Agricultura, quando iniciou pesquisas sobre doenças de peixes de água doce provocados por tripanosomas (1934) e ciliados (1934), a influência dos resíduos industriais sobre a poluição das águas interiores (1934), este último em colaboração com J. R. A. Guimarães e F. Bergamin, e vermes da garoupa vermelha (1934), em colaboração com R. D. Silva. Em companhia deste último esteve em Abrolhos e Rocas, de maio a agosto de 1935, coletando dados biológicos sobre ${ }^{+}$peixes (1936), aves (1936) e crustáceos (1937). Eles foram os pioneiros na divulgação de dados sobre as nossas lagostas em 1937, hoje um dos principais produtos de exportação do Ceará.

Em 1936 já estava interessado na criação do apaiari, Astronotus ocellatus, em colaboração com $\mathrm{H}$. Müller, tendo estudado também a nocividade do vinhoto sobre a fauna ictiológica.

Em 21 de dezembro de 1938 Faria foi designado Diretor do Serviço de Caça e Pesca, que dois dias depois passou a ser Divisão de Caça e Pesca do Departamento Nacional da Produção Animal, do Ministério da Agricultura, pelo Decreto n. 982, ficando nesse cargo até 1946. Voltaria mais tarde ao cargo, nele ficando até a sua aposentadória, em junho de 1960. Durante sua primeira gestão foi aprovado o Código de Caça, tendo construído diversos entrepostos no país, postos de piscicultura, parques de refúgio, Escola de Pessca de Tamandaré, etc.

Em 12 de abril de 1947 foi designado professor de Caça e Pesca, para lecionar no Curso de Aperfeiçoamento e Especialização do Ministério da Agricultura e, a 10 de outubro do mesmo ano, passou a chefiar a Secção de Criação, quando comẹçou a estu- 
dar a viabilidade da introdução de espécies alienigenas em alguns cursos de água. Ele analisou as condições limnológicas dos rios da Serra da Bocaina, SP, e elaborou um plano para a introdução da truta arco-íris. Importou 5.000 ovos embrionados, que vieram de avião, procedentes das criações em Esbjerg, Dinamarca, e levados para a Fazenda Nova Califórnia, na referida serra. Os ovos, incubados em cochos de arraçoamento de gado, deram origem a 3.500 alevinos, tendo sobrevivido 2.500 , os quais foram lançados nos rios Jacu Pintado e Bonito. As observações sobre seu desenvolvimento sofreram um hiato, devido a uma violenta e inesperada enchente, que arrastou os peixes para outro local, em maio de 1949. Então a Divisão de Caça e Pesca instalou um Posto de Biologia e Criação de Trutas às margens do rio Jacu Pintado e importou mais 50.000 ovos embrionados da Dinamarca, em maio de 1950. Em junho e julho desse ano foram lançados 7.500 alevinos nesse rio e 6.500 em outros riachos da região.

Em 1 de julho de 1951 um morador da região observou a subida de trutas no rio Bonito, dirigindo-se para as cabeceiras do rio Jacu Pintado, quando vários casais desovaram em diversos pontos desse rio. Em princípios de agosto de 1951 a totalidade das fêmeas do rio Bonito havia desovado. A observação da primeira desova foi feita no dia 3 de agosto de 1951 , das 14 às 18 horas. Os ovos eram pequenos, arredondados, medindo $3 \mathrm{~mm}$ de diâmetro, amarelo-claros, assemelhando-se à cor da areia do fundo dos rios. Em 1953 há registro de captura de exemplares de até $59 \mathrm{~cm}$ de comprimento total e $2 \mathrm{~kg}$ de peso, mostrando que elas tinham se adaptado bem à região. Hoje há vários criadores instalados nessa região, havendo alguns que chegam a produzir $30 \mathrm{~kg}$ por m $\mathrm{m}^{2}$, ou seja, $300 \mathrm{t}$ ha/ano, sendo elas vendidas nos mercados de São Paulo e Rio de Janeiro.

Ascânio publicou muitos artigos de divulgação sobre criação de trutas, principalmente nas revistas "Seleções Agrícolas" (1948 a 1953) e "Revista Nacional da Pesca" $(1969,1976)$. Outros artigos seus se referem à criação de carpas e outras espécies, indústria pesqueira, pesca esportiva, entrepostos de pesca, etc. e seus trabalhos científicos apareceram na "Revista do Departamento Nacional de Produção Animal" (1934-1937), "A Voz do Mar" (1935-1937), "Revista de Caça e Pesca do Brasil" (1945), "Boletim do Ministério da Agricultura" (1942) e em folhetos editados pela Divisão de Caça e Pesca.

Devemos a Ascânio de Faria, sem dúvida alguma, o estudo pioneiro da fauna de Abrolhos e Rocas e a introdução bem sucedida da truta arco-íris. 